\title{
Application of water efficiency to the building, as per IGBC Green existing building operation and maintenance rating system
}

\author{
Shubhra P. Dagwal ${ }^{1}$, R. Mahadeva Swamy ${ }^{2}$, Yashvant S. Patil ${ }^{3}$ \\ I'Civil Engg. Department/Shivajirao S. Jondhale College of Engineering and Technology, Asangaon/Mumbai \\ Univercity) \\ ${ }_{2}^{2}, 3($ Prof.,Civil Engg. Department/Shivajirao S. Jondhale College of Engineering and Technology, Asangaon/ \\ Mumbai Univercity)
}

\begin{abstract}
: igbc green existing buildings o\&m rating system is fundamentally designed to address national priorities of resource conservation while providing quality of life for occupants. the rating programme uses well accepted national standards and wherever local or national standards are not available, appropriate international benchmarks have been considered for water conservation.
\end{abstract}

Keywords: green existing buildings, water conservation. Resource conservation, benchmarks,IGBC.

\section{Introduction}

The building footprint in India is growing at a rapid pace and is contributing immensely to the growth of the economy. This augurs well for the country and now there is an imminent need to introduce green building concepts in this sector, which can aid growth in a sustainable manner.

Green practices in the existing buildings can help address national issues like water efficiency, energy efficiency, and reduction in fossil fuel use in commuting, handling of waste and conserving natural resources. Most importantly, these concepts can enhance occupant health, happiness and well-being. Most of the Asian countries are water stressed and in countries like India, the water table has reduced drastically over the last decade. Green Existing Buildings O\&M Rating System encourages use of water in a selfsustainable manner through reducing, recycling and reusing strategies. By adopting this rating programme, green existing buildings can save portable water to an extent of $15-30 \%$.

\subsection{Need}

- Water conservation is important because it keeps water clean and pure and conserves the environment. It is also important because the supply of water is not endless. About 2 percent of Earth's fresh water is locked in glaciers and ice caps, while 97 percent is salt water. Therefore, only 1 percent of water on Earth is available for drinking.

- Water conservation involves refraining from water pollution. It is important because, currently, only about 10 percent of Earth's waste water is disposed of appropriately, discloses About.com. In addition, water conservation saves money, minimizes the effects of water shortage and ensures that future generations have an adequate water supply. Strategies used in water conservation include reducing wastage, preventing damaging water quality and improving the practices of water management.

- Household water conservation initiatives, such as the use of low-flush toilets, rainwater harvesting and use of low-flow taps are recommended. Industry applications, such as water-recycling systems and the use of waterless car washes also conserve water.

\subsection{Advantages}

- Saves money

- Protects drinking water resources

- Minimize water pollution and health risks

- Reduces the need for costly water supply and new wastewater treatment facilities

- Maintain the health of aquatic environments

- Saves energy to pump, heat, and treat the water. 
II. Requirements of Igbc Green Existing Building Operation And Maintenance Rating System For Water Efficiency And Points Each Carries.

\begin{tabular}{|l|l|c|}
\hline $\begin{array}{l}\text { WE Mandatory } \\
\text { Requirement }\end{array}$ & Water Efficient Fixtures & Required \\
\hline WE Credit 1 & Water Efficient Fixtures: 20\%,30\%,40\% & 6 \\
\hline WE Credit 2 & Rain Water Harvesting: 25\%, 50\% & 4 \\
\hline WE Credit 3 & Waste Water Treatment, 100\% & 4 \\
\hline WE Credit 4 & Waste Water Reuse, 75\%, 100\% & 4 \\
\hline WE Credit 5 & Water Metering & 4 \\
\hline WE Credit 6 & Turf Area: 50\%, 25\% & 4 \\
\hline & & 26 \\
\hline
\end{tabular}

\section{WE Credit 1}

Water Efficient Fixtures: $20 \%, 30 \%, 40 \%$

\begin{tabular}{|c|c|c|c|}
\hline Fixture Type & $\begin{array}{c}\text { Maximum Flow Rate/ } \\
\text { Consumption }\end{array}$ & Duration & $\begin{array}{c}\text { Estimated daily uses per } \\
\text { person* }\end{array}$ \\
\hline Water Closets & $6.0 \mathrm{LPF}$ & 1 flush & $\begin{array}{c}1 \text { for male; } \\
3 \text { for females }\end{array}$ \\
\hline Faucets / taps & $8.0 \mathrm{LPM}$ & $0.25 \mathrm{~min}$ & 4 \\
\hline Urinals & $4.0 \mathrm{LPF}$ & 1 flush & 2 for males \\
\hline
\end{tabular}

points : 2, 4, 6

Intent

To enhance water use efficiency and minimize the use of potable water

Compliance Options

Use water efficient plumbing fixtures whose flow rates less than the baseline criteria, individually or in aggregate. The baseline criteria are as under:

The points are awarded as below:

\begin{tabular}{|l|l|}
\hline $\begin{array}{l}\text { Percentage of potable water savings } \\
\text { over } \\
\text { baseline }\end{array}$ & Points \\
\hline $20 \%$ & 2 \\
\hline $30 \%$ & 4 \\
\hline $40 \%$ & 6 \\
\hline
\end{tabular}

\section{WE Credit 2}

Rain Water Harvesting: $25 \%, 50 \%$

Points : 2, 4

Intent

Recharge the local aquifer or capture rain water to reduce potable water consumption.

Compliance Options

Have rainwater harvesting systems in place, to capture at least $25 \%$ of run-off volumes from roof and non- roof areas. The harvesting system have to cater at least 1 day of normal rainfall occurred in the last 5 years.

Points are awarded as below:

\begin{tabular}{|l|l|}
\hline $\begin{array}{l}\text { Percentage of Rainwater harvested onsite } \\
\text { from roof \& non - roof areas }\end{array}$ & Points \\
\hline $25 \%$ & 2 \\
\hline $50 \%$ & 4 \\
\hline
\end{tabular}

In areas where the Central/ State Ground Water Board does not recommend artificial rain water recharge (or) if the groundwater table is less than $4 \mathrm{~m}$, the projects can show nominal compliance by collection $\&$ reuse and points are awarded as below:

\section{WE Credit 3}

\begin{tabular}{|l|l|}
\hline Rainwater Harvesting System to Capture & Points \\
\hline $10 \%$ from roof \& non-roof areas & 2 \\
\hline $20 \%$ from roof \& non-roof areas & 4 \\
\hline
\end{tabular}

\section{Waste Water Treatment: $100 \%$}

Points: 4

Intent

Treat waste water generated on site so as to make it available for reuse or safe disposal and hence avoid polluting the receiving streams 
Compliance Options Have on-site treatment systems to treat $100 \%$ of waste water generated in the building / campus, to the quality standards suitable for reuse as prescribed by Central (or) State Pollution Control Board (CPCB), as applicable.

\section{WE Credit 4}

Waste Water Reuse, $75 \%, 100 \%$

Points: 2, 4

Intent

Use treated waste water thereby reducing dependence on potable water. Compliance Options Demonstrate that the treated waste water from waste water treatment plant is being reused for irrigation/ cooling water make-up/ flushing water requirements. Points are awarded as under:

\begin{tabular}{|l|l|}
\hline Percentage of Treated Water Reused & Points \\
\hline $75 \%$ & 2 \\
\hline $100 \%$ & 4 \\
\hline
\end{tabular}

\section{WE Credit 5}

\section{Water Metering}

Points : 4

Intent

Ensure continuous monitoring of water consumption, both on supply and demand side, to identify improvement opportunities in potable water efficiency.

Compliance Options Demonstrate water monitoring for the following, as applicable:

- Water consumption through bore well

- Municipal water supply

- Water consumption of each tenant in multi- tenant spaces (as applicable)

- Water purchased from external sources like tankers

- Water consumption/ supply for flushing

- Water consumption/ supply for irrigation requirements

- Any other major consumers of water consumption

\section{WE Credit 6}

Turf Area: $\mathbf{5 0 \%}, \mathbf{2 5 \%}$

Points : 2, 4

Intent

Minimise the extent of turf areas in landscaping to reduce potable water consumption.

Compliance Options Have limited turf onsite. The points are awarded as below*:

\begin{tabular}{|l|l|}
\hline $\begin{array}{l}\text { Turf Area as a Percentage of } \\
\text { Total Landscaped Area }\end{array}$ & Points \\
\hline $50 \%$ & 2 \\
\hline $25 \%$ & 4 \\
\hline
\end{tabular}

This credit is applicable for projects where in the landscape area is greater than or equal to $15 \%$ of the overall site area.

\section{Conclusion}

As all requirements is mention above to conserve water properly in case of existing building. These are some guide line for effective conservation of water.

\section{References}

[1]. IGBC Green Existing Buildings O\&M Rating System-Pilot Version

[2]. Water Conservation and Rainwater Harvesting S.P. Deolalkar (3 September 2015).

[3]. Rain Water harvesting at National Institute of Technology, Rourkela, By Ranjitkumar Sharma. (2010)

[4]. Evaluation of Rainwater Harvesting Methods and Structures Using Analytical Hierarchy Process for a Large Scale Industrial Area. V. Jothiprakashi, Mandar V. sathe. Published Online December 2009 (http://www.scirp.org/journal/jwarp)

[5]. Rainwater Harvesting: Grab hold of Water where it Falls! Mrs. S.D. Khandagale, Mrs. V.A. Joshi V.P.M's Polytechni, Thane, MS, India (june 2011)

[6]. Domastic Rooftop Water Harvesting- A Case Study Arun Kumar Dwivediand Sudhir Singh Bhadauria.VOL.4, NO. 6, (August 2009)

[7]. Rain Water Harvesting System for College of Engineering, TeerthankerMahaveer ,University, Moradabad., S Rehan Ali, R K Jain,Vol. 3, Issue 8, August 2014

[8]. A rooftop rainwater Haevesting (RRWH) At SPSV Campus, Visnagar,Gujrat - A case study. Utsav R. Patel1, Vikrant A. Patel, Manjurali I. Balya, Harshad M. Rajgor, Volume: 03 Issue: 04 | Apr-2014, Available @ http://www.ijret.org 